\title{
System of Spiritual Values of Modern Youth: the European Dimension
}

\author{
Valerii Budak, Dr.Sc., Prof., \\ Academician of National Academy of Educational Sciences of Ukraine \\ Rector, Mykolaiv V.O. Sukhomlynskyi National University, Mykolaiv, Ukraine \\ e-mail:office@mdu.edu.ua \\ ORCID ID https://orcid.org/0000-0003-2698-6333 \\ Svitlana Zaskaleta, Dr.Sc., Prof. \\ Mykolaiv V.O. Sukhomlynskyi National University, Mykolaiv, Ukraine \\ e-mail: zaskaletas1@gmail.com \\ ORCID ID http://orcid.org/0000-0002-5417-2612
}

\section{Oksana Oleksyuk,} Candidate of Pedagogical Sciences, Associate Professor, Associate Professor of Pedagogy and Inclusive Education, the head of Scientific-Research Center of Military and Patriotic Education of

Mykolaiv V.O. Sukhomlynskyi National University, Mykolayiv, Ukraine

ORCID ID https://orcid.org/0000-0002-5527-3861, e-mail: oleksjukoksana@ukr.net

\begin{abstract}
The article deals with the problem of formation of spiritual values of modern youth. It is determined that a new type of personality is formed in the youth environment, which will dominate and develop in the future. The study showed that important components in the formation of the value system of student youth are the formation and development of moral values in a multicultural society, the formation and development of tolerant thinking, understanding and respect for other people's feelings and thoughts, the influence of moral values on the formation and development of tolerant thinking.
\end{abstract}

Keywords: student youth, values, value system, European dimension, European values.

Socio-economic and political transformations taking place in Ukraine actualize the problem of formation of spiritual values of youth. The formation of the spiritual values of the Ukrainian nation requires special attention to the formation of the system of values of modern youth, which is the guarantor of the future of the country and social progress. The problem of educating the spiritual world of student youth is of paramount importance today. After all, the value orientations of the individual are not only the basis of education, but also the key to the implementation of the most important ideas and goals, the implementation of which is the meaning of human and social existence. Unfortunately, due to the decline of the value system 
that has existed for decades, low morals and neglect of culture have become the norm in everyday life. Every day we witness that such universal values as humanism, honor, decency, conscience, empathy, love and friendship, etc., are leveled in society. They are replaced by unjustified resentment, selfishness, indifference to others, contempt for honor and conscience, falling cultural standards. The victims of all these «new changes», first of all, are the souls and hearts of those whose personality is just being formed.

We can not disagree with the opinion of Morozova L.P. that in the conditions of deep crisis of economy, culture, ideology, morality, education and upbringing our youth more and more loses spiritual and world-view targets, does not feel firm ground at formation of life plans, is confused in universal values. The rapid flow of critical and negative information pouring from the pages of newspapers and magazines, from the TV screen, from the radio, the difficult realities of life seriously affect the unstable consciousness of young men and women. Along with the exposure of false ideals, valuable life ideals that are of inalienable significance are also eroded [1].

The process of modernization of Ukrainian education in higher education obviously requires the creation of such a system of values that would serve as a guide in educating the younger generation as patriotic individuals with a globalizing understanding of the current state of society.

Almost two hundred years ago, J. Fichte insisted that any nation or its individual representatives, who are mechanically borrowing other people's spiritual values, types of thinking, lose the ability to create something new both within their native and foreign culture.

I. Franko's views on the factors of universal progress (free labor, freedom as the highest ideal, the highest human value) and the main tasks of the formation of the Ukrainian nation, which can repel the assimilation aspirations of other nations, but at the same time must be inseparable associated with the universal.

In opposition to the new, in particular the negative challenges of our time, we should pay attention to the opinion of Vovchasta N.Ya. and to restructure the system of educational work with student youth, to raise their prestige, to make certain changes in its ideology, content characteristics and specific actions [2]. 
That is why in the State National Program «Education (Ukraine of the XXI century)» the leading values of education of the Ukrainian nation were patriotism, citizenship, humanism, tolerance, conscience, honor, love, friendship, diligence.

Many studies Ukrainian and foreign education scientists devoted to the analysis of the spiritual values of young people. It is necessary to mention the works of V. Andrushchenko, I. Bekh, E. Bondarevskaya, M. Boryshevsky, I. Zyazyun, A. Kapskaya, V. Kirsanov, N. Nychkalo, G. Sagach, O. Sukhomlinskaya, T. Tyurin, J. Zimny, R. Krul, S. Slavinsky, M. Volitsky and others. This problem was also studied in depth by O. Belykh, V. Dolzhenko, B. Nagorny, O. Semashko, D. Chernylevsky, G. Shevchenko, V. Yakovenko and others.

It should be emphasized that the formation of a new educational paradigm is taking place today in accordance with the general philosophical and psychological issues through the prism of both socio-cultural and anthropological dimensions. This allows from new positions to understand the essence of spiritual and worldview consciousness and develop approaches to its formation during the educational process. In affirming the idea of integrity in relation to the understanding of the individual, modern pedagogical science is based on the general philosophical principle of internal interconnection and interdependence of processes and phenomena of the world. Regarding modern philosophical and pedagogical research related to the problem of formation and development of the worldview of the individual, there is a view that spirituality is the core in understanding this phenomenon [3:46].

Value orientations of the individual is one of the main characteristics of the individual, and their development - the main task of the modern education system, as the value system is the foundation of education, the most important ideas and goals, which see the meaning of human existence and society.

During the transformation of modern society, this question acquires special significance, because the formation of value orientations of student youth is influenced by the integral interaction of two integral systems. On the one hand, social life influences the personality of young people, on the other hand, the personality actively assimilates the previous actual experience of society, knowledge, norms, values, traditions, and knowledge. At the same time, young people influence the development of society.

Boryshevsky M.Y. believes that now there is a need to form new value orientations, new value ideals, value worldview of a person who will live and work in the XXI century in 
Ukraine - an independent European state, where target and value orientations will combine creativity, new original ideas with folk traditions and culture. [4].

The student years are a period when the development and upbringing, the formation of the personality, and the professional training of future specialists take place especially intensively, as if at an accelerated pace. This is a period for the development of intelligence, revision and development of the value system, strengthening health and physical strength. Teachers working with students should have a good idea of the features and opportunities of this period in the lives of students, in their professional and civic development, as well as their role in these processes, in particular in solving problems of education.

Students are an integral part of youth, its specific group, characterized by special conditions of life, life and work, social behavior and psychology, a system of value orientations. That is, students should be considered as a social group in the system of higher education, which has its own purpose, its own specific features and which is preparing to perform social roles and functions of the intelligentsia. Students are a mobile group, the purpose of whose existence is organized according to a certain program of preparation for professional and social roles in material and spiritual production. Working together contributes to the development of students' cohesion and collectivism.

The process of learning in a higher education institution involves the inclusion of students in the system of social relations, substitution of positions and the assimilation of social values. An important feature of students is that active interaction with various social formations of society, as well as the specifics of university education create great opportunities for students to communicate. Therefore, a fairly high intensity of communication is a specific feature of students. The student acts as a subject of educational activity, which is primarily determined by two types of motives: achievement motivation and cognitive motivation. Cognitive motivation is the basis of educational and cognitive activity of man, corresponding to the very nature of his mental activity. In teaching, the motivation to achieve is subject to cognitive and professional motivation. Thus, the student as a subject of activity has his own goal, his own motives, his own object, his own ways to achieve the goal, his own opportunities.

The student age has a process of active formation of social maturity. Social maturity involves the ability of each young person to master the necessary set of social roles for society 
(specialist, father, mother, public figure). Students have an increased interest in moral issues (purpose, lifestyle, responsibilities, love, loyalty, etc.). Purposefulness, determination, persistence, independence, individuality, initiative in the process of activity and communication, ability to control oneself increase. It is known that in adolescence, desire and aspiration develops earlier than the will and character.

The attitude of the student as a socially mature person, the bearer of the formed worldview to the future citizens of the country presupposes taking into account that the student has not only a certain system of views on the world, but also on his place in this world. That is, in the organization of educational work it is necessary to develop the student's reflection and awareness that he is the bearer of certain universal values (values), socially significant personality. Based on the above, it can be argued that students are part of youth, its specific group, characterized by special conditions of life, life and work, social behavior and psychology, the system of value orientations. That is, students should be considered as a social group in the system of higher education, which has its own purpose, its own specific features and which is preparing to perform social roles and functions of the intelligentsia.

Education in higher education, in particular in the pedagogical field, should be professionally oriented. The process of its organization is permeated by the idea of training a young specialist of a certain type, a teacher who is needed by society, school, children. The professional orientation of education is expressed primarily in the formation of students' pedagogical orientation and attitude to pedagogical activity as a value. The process of education is associated with the formation of students' views, beliefs, qualities, values, attitudes, abilities. These are the most significant structural components of the personality, which are its affiliation and accompany it everywhere - in learning, activities, communication, behavior. The educational process is not a simple sum of its components, they are interdependent, intertwined in the life of the educational institution, interact, often complement each other. In this process, a holistic personality of the future professional is formed.

Discussions in the UN General Assembly commemorating the tenth anniversary of International Youth Year [5] noted that teaching moral values to youth and responding to their spiritual needs was a key to addressing their current problems.

The following issues were highlighted: 
1) It is imperative to preserve those moral values that provide a spiritual balance for young people and reinforced the family as the fundamental institution of society. It would be well worth it to provide students with an introduction to human rights issues.

2) The world, especially its youth, is suffering from a moral crisis that has been on a huge scale in many societies. To prevent an identity crisis, the international community must meet the spiritual needs of young men and women, as well as their temporary needs.

3) The place of education in preparing young people for their role in society is highlighted. It is noted that the goals of his country's educational programs are to strengthen the sense of belonging of young people and prepare them for citizenship in civil society on the basis of moderation, justice and tolerance.

4) It is emphasized that young people remain on the sidelines of education in some countries, and this is an important source of frustration. This situation was due to a lack of resources, which affected 50 percent of young people, the need to work for others, and the fact that some did not value education.

5) It is noted that education in its various forms should focus on the abolition of technical illiteracy. Rapid technological progress creates problems that must be addressed by the education system so that young people can avoid marginalization.

Exploring the problem of forming the spiritual values of modern youth, it is important to attract attention to the European vector of solving this. According to the Lisbon Strategy for the Development of Education and Training (Europe-2010), the European dimension in education includes: in addition to European knowledge, European language competence, European citizenship, European quality of education, European professionalism, also European identity. The Resolution of the Council and Ministers of Education of the European Community (1988) on the European dimension in education sets out four objectives for the European dimension: strengthening young people's sense of European identity and the value of European civilization, which is important for democracy, social justice and respect to human rights; preparing young people for participation in the economic and social life of the European Community; promoting young people's awareness of the benefits of the Commonwealth, as well as the challenges it faces; strengthening the knowledge of young people about the history, culture and economy of European countries, which will promote the development of cooperation. 
The urgency of the problem of forming the moral values of student youth is confirmed by numerous studies in the countries of the European educational space. Thus, researchers from Estonia, Germany, Latvia and the Czech Republic have covered the impact of moral values on the formation of tolerant thinking [4].

6) The study showed that important components in the formation of the value system of student youth are the formation and development of moral values in a multicultural society, the formation and development of tolerant thinking, understanding and respect for other people's feelings and thoughts, the influence of moral values on the formation and development of tolerant thinking. (The project was supported by the European Community Youth in Action Program).

Ukraine, as a European country, does not stand aside from solving these problems. The value orientations of the youth as the most «dynamic» group of society are more prone to change than others. It is in the youth environment that a new type of personality is formed, which will dominate and develop in the future. Value orientations, spiritual values are the main vectors of social orientations. They determine the orientation of the individual and the degree of its socialization, which change depending on the degree of conformity of individual needs and interests to the needs and interests of society. This causes the problem of forming the value orientations of young people both for today's social policy and for future prospects of social development.

In order to create a system-as orientation of spiritual values, it is necessary to determine the current aspirations, goals, desires of the younger generation.

The prospect of further research is the analysis of the results of psychological research conducted among students «Methods of research of value orientations» in order to determine the respondents' goals that are decisive for them (values-goals) and specific personality traits needed to achieve them (values-means).

\section{References}

1) Morozova L.P. Aspects of the formation of the value world of youth // Scientific notes: special issue. - Kyiv: KM Academy Publishing House, 2003. - Vol.21. - C. 94-102.

2) Vovchasta N.Ya. Spiritual values as an integral part of modern education of students // Proceedings of the scientific-practical Internet conference «Ukrainian science of the XXI century June 25 - 27, 2008». 
3) Podolyak L.G., Yurchenko V.I. Psychology of food schools: Pidruchnik. 2nd view. - K .: Karavela, 2008 .-- 352 p.

4) Boryshevsky M.J. Spiritual values of youth in the formation of the citizen's personality // Pedagogy and Psychology. - № 1, 1997.

5) Influence of the moral values on formation of tolerant thinking https://clubactive.eu/portfolio/influence-of-the-moral-values-on-formation-of-tolerantthinking/

6) MORAL VALUES AND SPIRITUAL NEEDS KEY TO ADDRESSING YOUTH PROBLEMS, SAY SPEAKERS IN GENERAL ASSEMBLY. Press Release GA/8978 https://www.un.org/press/en/1995/19951027.ga8978.html 